\title{
An Analysis of Learners' Motivation and Attitudes toward Learning English Language at Tertiary Level in Turkish EFL Context
}

\author{
Zubeyde Sinem Genc ${ }^{1} \&$ Fulya Aydin ${ }^{2}$ \\ ${ }^{1}$ Faculty of Education, Uludag University, Bursa, Turkey \\ ${ }^{2}$ School of Foreign Languages, Uludag University, Bursa, Turkey \\ Correspondence: Zubeyde Sinem Genc, ELT Department, Faculty of Education, Uludag University, Bursa, \\ Turkey. Tel: 90-224-2942267. E-mail: zsgenc@yahoo.com
}

\author{
Received: January 26, 2017 Accepted: March 4, 2017 Online Published: March 6, 2017 \\ doi: 10.5539/elt.v10n4p35 URL: http://doi.org/10.5539/elt.v10n4p35
}

\begin{abstract}
The purpose of this study is to investigate Turkish students' ( $\mathrm{n}=462)$ motivation and attitudes toward learning English as a foreign language at a state university in Turkey and the relation between their attitudes, motivation and the variables such as gender, parental involvement, their fields of study at university, and academic achievement. It was important to explore and comprehensively look at the issue through a range of variables because the findings of the previous studies have revealed inconsistent attitudinal profiles toward learning English language. The study adopted quantitative research paradigm and used a questionnaire for data collection. The results indicated that the participants' instrumental and intrinsic motivation were at moderate level while the mean of parental involvement was at a high level. It was also shown that the learners' attitude changed according to their gender, fields of study and academic achievement. Alternative solutions at individual and institutional levels have been proposed in order to develop motivation and more favourable attitudes toward learning English language, and to prevent the generalization of stereotypes, which may have great impact on the success of learning English language at tertiary level.
\end{abstract}

Keywords: learners' attitudes, motivation type, learning English at tertiary level, Turkish EFL context

\section{Introduction}

\subsection{Introduce the Problem}

One important characteristic of learning a foreign language is the degree of variation in the levels of proficiency learners eventually reach. Factors such as quality and quantity of input, age, aptitude and attitude have been proposed to account for this variation (Bidin et al., 2009; Friedrich, 2000; Frrat, 2009; Gömleksiz, 2010). The attitudes of learners, teachers, parents, and native speakers of the language are quite significant and determine the ultimate level of success in the learning process. One of the most important factors is the attitude of learners toward the target language and its speakers. Comparing a person's attitude toward a foreign language and his level of success in learning that language may help to illustrate the correlation between these variables. When the role of attitude in language learning is considered, we need to understand Gardner and Lambert (1972), who pointed to the role of learners' attitude toward the target language as the most significant component affecting language acquisition. Likewise, Williams and Burden (1997) state “... learners bring many individual characteristics to the learning process which will affect both the way in which they learn and outcomes of that process". For that reason, as Mantle-Bromley (1995) mentions, if attitudes affect the endeavours of learners to learn another language, teachers of foreign languages should be knowledgeable about this concept, so that they can deal with issues regarding attitudinal handicaps in language classrooms. Furthermore, Chambers (1999:25) clarifies that "pupils do not come to the foreign languages classroom as tabulae rasae. They bring with them some attitudes born of conversations shared with family, friends, the media and personal experience of the target language community." It becomes quite crucial to investigate whether and what factors affect the attitudes of language learners positively or negatively.

Having negative attitudes toward the target language can cause demotivation and cause learners to eventually give up. On the other hand, having positive attitudes toward the target language can lead high levels of motivation and facilitate the learning process. Therefore, examining learners' attitudes toward a foreign language 
is a significant issue and plays a key role in language learning and teaching.

\subsection{Importance of the Problem}

In any context of learning a foreign language, learners bring positive or negative emotions about several aspects of the target language to the class, and eventually develop attitudes toward the language itself, the teacher, the course in general, one's classmates, the course materials, and extra-curricular activities associated with the course. It is also possible that the attitude and the type of motivation a learner develops about a foreign language may determine whether one will be successful in learning that language or not.

Previous studies have shown that learners' attitudes toward English as a foreign language (EFL) are prone to a number of factors which clearly affect the learning process and that the effects of these factors may exhibit variety from one context to another. The previously conducted studies had their unique socio-cultural context. Although we can have access to a rich literature on the aspects of attitudes towards learning English language in other countries, there have been few studies focusing on the factors that influence attitudes of students at tertiary level in the context of Turkey (Aydın, 2007; Çolak, 2008; Şeker, 2003). When the significance of learning English language is considered in Turkey, universities have a great role and responsibility in improving the proficiency level of students in English language. Learners have to be proficient in English to study in their departments since they have to take several English courses throughout their academic studies at universities.

Although learners are exposed to English instruction for a long time at different levels in Turkey, the reasons for the poor English language skills of learners have long been a matter of discussion among researchers and educators. There are many students failing in preparatory English language courses offered at the beginning of undergraduate programs at universities (Çolak, 2008). It seems obvious that more comprehensive and extensive studies of attitudes toward English language among university students in Turkey are needed in order to contribute to the success of learners of English as a foreign language and to the procedures of learning English language in Turkey.

Studies in Turkish EFL context showed that EFL learners had high levels of instrumental motivation toward English (Kıziltepe, 2000; Saracaloğlu, 2000; Üzüm, 2007) and that their attitudes correlated positively with high levels of parental support (Demirtaş, 2007). However, we need to have further evidence since there are few studies showing the significance of the attitudinal factors in language learning in this regard. Furthermore, the studies so far focused on one or two factors at one time and only a few of them examined the effects of attitudinal factors at tertiary level. It is obvious that various variables affecting the attitudes as examined within one group of Turkish EFL learners are missing points of discussion when the problems of teaching English language in universities in Turkey are considered.

\subsection{Relevant Scholarship}

The key terms used in the study need to be defined briefly before relevant studies were reviewed. Attitude refers to one's likes and dislikes. Gardner (1985) defines attitude as an evaluative reaction to some referent or object, inferred on the basis of the individual's beliefs or opinions about the referent. Definitions of 'attitude' emphasize that it is an individual act having the roots in social environment mostly and results with stable opinions for the target topic. It is related to person's feelings and shapes his/her behaviors. People develop positive or negative attitudes towards everything and their attitudes may stem from various sources.

Intrinsic motivation involves a behaviour performed to experience pleasure or satisfying one's curiosity, whereas instrumental motivation is related to a behaviour to receive some extrinsic reward such as better employment opportunities, better grades, or some kind of benefit or advantage for the person. Intrinsic motivation refers to the desire and willingness to engage in an activity for the sake of satisfaction rather than for some other seperable consequences or reasons, which are important in instrumental motivation. Academic achievement in this study refers to the EFL learners' success in learning English language in the context of the investigation.

Today, researchers have become increasingly interested in learners' motivation and attitudes toward English language since English language has become the international language used by speakers of other languages in the world. The studies demonstrate that learners in different contexts attributed a mixture of feelings toward English language and inconsistent attitudinal profiles have been revealed in the previous studies conducted on this crucial issue (Bidin et al., 2009; Cortes, 2002; Friedrich, 2000; Hang, 2009; Thomas, 2010; Young, 2006).

Different factors influence attitudes of learners such as social environment, peers, instrumental reasons, culture, age, gender and achievement. Unfortunately, there are not many studies focusing on the effects of various factors in the same group of learners. In other words, previous studies usually showed the significance of the factors separately instead of examining them all in one study with the same group of learners of English language. For 
example, Ryan and Deci (2000) explained intrinsic motivation as the desire to engage in an activity for its inherent satisfaction rather than for some separable consequences. The intrinsically motivated learner was expected to maintain his motivation with or without any external rewards. Another study by Small (1997) showed that intrinsically motivated learners usually display intellectual curiosity, find learning fun and go on seeking knowledge even after the formal instruction classes are over.

In Turkey, English is learned as a foreign language for mainly instrumental motivation regarding education and better career opportunities (Sebüktekin, 1981). A review of literature clearly shows that one of the most important instrumental motivation for learning English in Turkey is job requirement (Doğancay- Aktuna, 1997; Kızıltepe, 2000; Qashoa, 2006; Üzüm, 2007). Other instrumental reasons are being successful in their field of study, gaining self-respect, having a social status (Al-Tamimi \& Shuib, 2009; Malallah, 2000; T1lfarlığlu and Kınsiz, 2011). As Konig (1990: 4) says, "more and more people are aware of the fact that at least some knowledge of English is necessary to get ahead in life. It brings high status to the individual socially, as well as extending job opportunities."

An important factor observed to affect learners' attitude toward a foreign language is gender. Though many studies show the effect of gender on learners' attitudes, the results are still inconsistent (Atl1, 2008; Aydın, 2007; Gömleksiz, 2010; Kobayashi, 2002). Females and males have often been reported to develop different levels of attitudes toward English language. The gender differences in attitudes toward language learning are explained with three different aspects of language learning: these are cultural effects, employment needs and image of the target language (Rees, 1987; Spolsky, 1989; Kobayashi 2002). In some cultural contexts, certain society forms that do not support female achievement have adverse effects on the development of attitudes toward the language (Hawley, 1971). Another explanation for the gender difference is that higher future employment possibilities open to girls resulted with females' more positive attitudes (Loulidi, 1989). Furthermore, as Pennycook (2004) and Carr and Pauwels (2006) indicated, learning a foreign language was usually considered to be a 'girl-appropriate' subject.

Another social phenomenon directly related to language learning is the role of parents (Demirtaş, 2007; Kızıltepe, 2000; Tavil, 2009). For example, Fullan (2001:198) states that "the closer the parent is to the education of the child, the greater the impact on child development and educational achievement". Likewise, Gardner (1985) concludes that parents with positive attitudes play an integrative role in students' motivation whereas the development of learners' positive attitudes can be inhibited by parents' negative attitudes.

Although it seems that learners' fields of study have an effect on their attitudes, a comprehensive review of literature shows that few studies have been conducted to closely investigate this factor. As an example, Çolak's (2008) study pointed out that there was a significant difference between students' fields and their attitudes towards learning English. Likewise, Gömleksiz (2010) also found out that the students' attitudes varied from one field to another, and revealed statistically significant differences between participants' fields of study and their attitudes toward learning English language.

Gardner and Lambert (1972) assert that there is a close connection between attitude and achievement; they point out that learners' attitude toward target language determine how successful they will be to learn that new language. Most of the studies reveal that there is a positive relationship between learners' attitudes and foreign language achievement (Haitema, 2002; Liu, 2007; Malallah, 2000; Petrides, 2006; İnal et al., 2005). However, unlike Gardner and Lambert (1972) and Saracaloğlu (2000), Karaş (1996) indicated that there was only a weak relationship between academic achievement and attitude.

\subsection{The Purpose of the Study and Research Questions}

The aim of the present study is to analyse motivation type and the factors that influence Turkish EFL learners' attitudes toward learning English language at tertiary level. The variables considered to have a relation with the attitudes of EFL learners include parental involvement, gender, learners' fields of study at university and academic achievement. To the knowledge of the researchers, there is not any study in Turkey that examines the effects of all these variables together with the same group of learners. Thus, the study was designed to address the following research questions:

1)- What are learners' attitudes toward learning English language at tertiary level in Turkish EFL context?

2)- To what extent do Turkish EFL learners at tertiary level have intrinsic motivation?

3)- To what extent do Turkish EFL learners at tertiary level have instrumental motivation?

4)- What are the parents' attitudes toward learning English as a foreign language? 
5)- Do Turkish EFL learners' attitudes toward learning English at tertiaty level differ according to their gender?

6)- Do Turkish EFL learners' attitudes toward learning English at tertiary level differ according to their fields of study?

7)- Is there a correlation between motivation type of Turkish EFL learners at tertiary level and their achievement?

\section{Method}

The study adopted quantitative research paradigm in data collection and data analysis procedures. The research was centred on the relation between variables under investigation. The study quests for facts on motivation and attitudes toward English language, which can be generalized beyond the particular context. In this regard, quantitative research design encourages generalizations and replications in similar teaching contexts in Turkey.

\subsection{Participants}

The study was conducted on 462 students at the School of Foreign Languages at a large state university in Turkey. 178 of them were male and 284 of them were female. After being admitted to the university, the students took an in-house proficiency exam in English language. Upon failing at the exam, they were required to study English language intensively at the School of Foreign Languages for one year. In order to start their undergraduate education in their departments at the university, they had to take and be successful at the proficiency exam administered at the end of one-year intensive English language instruction at the School of Foreign Languages. They were expected to obtain minimum 70 points out of 100.

\subsection{Instruments}

The quantitative data collection instrument was adapted from Gardner's (1985) 'The Attitude/Motivation Test Battery' (AMI). The items of the questionnaire focused on intrinsic motivation, instrumental motivation, parental involvement and attitudes. However, after implementing the pilot study with 70 intermediate level students, the questionnaire items were modified. Based on the findings obtained through a factor analysis in the pilot study, the number of items in the questionnaire were modified. The scale used in the questionnaire was a five-point Likert-type scale from strongly disagree to strongly agree. The reliability coefficient (Cronbach Alpha) value for the items in the questionnaire was .899 .

\subsection{Data analysis}

Statistical Package of Social Sciences (SPSS 20.0) was used in order to analyse the data gathered through the questionnaire. The statistics in the study included descriptive statistics with mean scores, t-test results, Kruskal Wallis Test and correlation analysis.

\section{Results and Discussion}

The analysis of the results was done to measure the attitudes of the learners toward learning English language. As can be seen in Table 1, a mean score of 3.70, a median of 3.79 and a mode of 4.13 on the attitudes toward learning English as a foreign language were obtained. This clearly showed that the Turkish EFL students at the tertiary level where the study was conducted had positive attitudes toward learning English.

Table 1. Descriptive statistics of learners' attitudes toward learning English

\begin{tabular}{ll}
\hline N Valid & 462 \\
\hline Missing & 0 \\
Mean & 3.70 \\
Median & 3.79 \\
Mode & 4.13 \\
Minimum & 1.34 \\
Maximum & 5.00 \\
\hline
\end{tabular}

Table 2 below illustrates that the mean of the students' intrinsic motivation was 3.47 , the mean of the students' instrumental motivation was 3.68 and the mean of the students' parental involvement was 4.13. 
Table 2. Descriptive statistics of motivation type and parental involvement

\begin{tabular}{llll}
\hline & Intrinsic motivation & Instrumental motivation & Parental involvement \\
\hline N Valid & 462 & 462 & 462 \\
Missing & 0 & 0 & 0 \\
Mean & 3.47 & 3.68 & 4.13 \\
Median & 3.64 & 3.80 & 4.25 \\
Mode & 4.00 & 3.80 & 4.50 \\
Minimum & 1.00 & 1.30 & 1.00 \\
Maximum & 5.00 & 5.00 & 5.00 \\
\hline
\end{tabular}

The top intrinsic motivation statement was: "Being successful in English is important for me." with a mean score of 3.89 while the item with lowest mean score was: "I hate English" $(\mathrm{m}=2.01)$. The top item of the instrumental motivation was: "Learning English is important to me because it will enable me to meet new people from different parts of the world" ( $\mathrm{m}=4.15)$. The bottom item was: "It is important for me to know English in order to better understand the English-speaking nations' behaviour and problems" $(m=3.20)$. When parental involvement sub- factor was examined, the top statement was: "My parents think that learning English is necessary for my academic career" $(\mathrm{m}=4.36)$ and the bottom statement was: "My parents think that English is an unimportant lesson" (m=1.44).

Table 3. T-test results of the learners' attitudes with respect to their gender

\begin{tabular}{lllllll}
\hline Groups & $\mathrm{N}$ & $\mathbf{X}$ & $\mathrm{SD}$ & $\mathrm{DF}$ & $\mathrm{t}$ & $\mathrm{p}$ \\
\hline Female & 284 & 3.80 & 0.54 & 460 & 4.36 & 0.000 \\
Male & 178 & 3.55 & 0.64 & & & \\
\hline
\end{tabular}

In Table 3, the results of the t-test demonstrated that there was a significant difference between the attitudes of the female and the male students $(\mathrm{t}(462)=4.36)$. In other words, the attitudes of the females towards learning English $(\mathbf{X}=3.80, \mathrm{SD}=0.54)$ proved to be higher than that of males $(\mathbf{X}=3.55, \mathrm{SD}=0.64)$.

Table 4. The results of Kruskal Wallis test for 'Attitudes' in terms of learners' fields of study

\begin{tabular}{lllllll}
\hline Field of Study & $\mathrm{N}$ & Mean Rank & DF & $\chi^{2}$ & $\mathrm{p}$ & Significant Difference \\
\hline A-Medicine & 76 & 178.81 & 6 & 28.35 & 0.00 & A-C, A-D, A-F \\
B-Education & 11 & 258.95 & & & & C-E \\
C-Engineering & 195 & 257.83 & & & & \\
D-Arts and Sciences & 114 & 229.27 & & & & \\
E-Veterinary & 48 & 192.55 & & & & \\
F-Foreign Trade & 7 & 336.43 & & & & \\
G-Maritime and Port Authority & 11 & 227.59 & & & & \\
\hline
\end{tabular}

For the difference between the students' fields of study and their attitude levels, Table 4 shows that there was a statically meaningful difference between Medicine and Engineering students. As Faculty of Engineering participants had higher mean score, it can be stated that they had more positive attitudes than the students at the Faculty of Medicine. Similarly, the students at the Faculty of Arts and Sciences and the Foreign Trade Department had higher mean scores than the studenst at the Faculty of Medicine. The results also revealed that there was a significant difference between Faculty of Engineering and Foreign Trade Department participants. It can be deduced that Foreign Trade students tended to have more positive attitudes compared to the students in the Faculty of Engineering. 
Another important point observed in the study was the relationship between participants' academic achievement and their attitudes. Pearson Correlation Coefficient analysis results demonstrated that there was a very low correlation between attitudes of the participants and their achievement. There was a low correlation between intrinsic motivation and achievement, $(\mathrm{r}=.187)$. There was also low correlation between instrumental motivation and achievement, $(\mathrm{r}=.124)$. However, there was not a significant correlation between parental involvement and students' academic achievement.

Table 5. The results of Pearson Correlation (2-tailed) for "Achievement" in terms of students' fields of study

\begin{tabular}{lccc}
\hline Field of Study & Intrinsic motivation & Instrumental motivation & Parental involvement \\
\hline Medicine & .062 & .003 & .090 \\
& .595 & .977 & .440 \\
Education & .341 & .429 & .223 \\
Engineering & .304 & .188 & .509 \\
& .210 & .042 & .105 \\
Arts and Sciences & .003 & .558 & .143 \\
& .431 & .398 & .071 \\
Veterinary & .000 & .000 & .452 \\
& .126 & .076 & .029 \\
Foreign Trade & .394 & .606 & .847 \\
& .221 & .029 & .490 \\
Maritime/Port Authority & .293 & .951 & .264 \\
& .371 & .008 & .502 \\
\end{tabular}

Table 5 reports the correlations between motivation type/parental involvement and achievement in terms of participants' fields of study. It is clear that there was no significant correlation between three sub-factors and achievement when participants' answers were examined for the Faculty of Medicine, Education, Veterinary, and Foreign Trade and Maritime and Port Authority Departments.

The results for the students at the Faculty of Art and Sciences showed that there was a moderate positive correlation between achievement, and both intrinsic motivation $(\mathrm{r}=.431)$ and instrumental motivation $(\mathrm{r}=.398)$. However, it is clear in Table 2 that there was no significant relation between achievement and parental involvement $(\mathrm{r}=.071)$.

As can be deduced from the results for Faculty of Engineering participants, there was positive but low correlation between intrinsic motivation $(\mathrm{r}=.210)$ and achievement factors. However, the findings showed that there was no meaningful relation between achievement and instrumental motivation, and between achievement and parental involvement factors. Open-ended responses indicated that the results also revealed that $87 \%$ of participants thought English language was important, and that 37.6\% of them hoped to find a better job if they know English. This constituted the most important reason for learning English. 32.3\% of them believed that having the opportunity of education or finding a job abroad was the second most popular reason. Having a good social status was the third important reason for learning English as 29.9\% of the participants chose the item. More than half of the parents had no knowledge of English. Parents totally supported students to learn English. They even encouraged them to learn other languages. The results also revealed that nearly all of the participants $(95.2 \%)$ would like to learn English even if one-year intensive English instruction at the university was not obligatory.

A correlation between positive attitudes and their intrinsic motivation, instrumental motivation and parental involvement was observed for a considerable majority of the students. Participants were aware of the importance of learning English and they expressed that they loved English language and they were intrinsically motivated to learn English as a foreign language. The participants were conscious about how success in learning English might affect their lives and they were really motivated to be successful in English. The reason for this might be 
related to the effects of the proficiency exam required by the University. The participants displayed a natural curiosity and preferred to study English even when it was not obligatory at the School of Foreign Languages.

The fact that the participants want to be in contact with foreign people can be supported with the great tourism potential in Turkey hosting large numbers of tourists every year, which creates an English-speaking environment with part-time jobs for especially university students in different seasons. It can also be related to the opportunities of meeting new people in social media thanks to internet in recent years. Other important motives for the participants for learning English included finding better job or education opportunities abroad, gaining a good social status thanks to communicating in English, understanding songs and films in English showing their admiration and appreciation towards the cultural products of the target language. They were willing to go abroad. However, they were not deeply interested in the behaviours or problems of people in English-speaking cultures.

Parents totally supported the participants to learn English and were aware of the importance of English in learners' academic career and in job market eventually. Parents not only guided learners to learn English but they also encouraged them to learn other languages as well. The parents' past experiences, their lack of knowledge in English language may possibly shape their attitudes toward their children's learning English (Hoover-Dempsey et al., 2005). Another conclusion is that female learners tended to demonstrate significantly more positive attitudes than male students do. This result shows parallelism with the study by Saracaloğlu (2000) and Atlı (2008).

The question whether attitudes of learners differ according to their fields of study indicated that students enrolled at the Faculty of Engineering, Arts and Sciences and Foreign Trade Department tended to have more positive attitudes than Faculty of Medicine students. The main reason for this could be that these students study English only in English courses, which does not meet their needs because they will be working in Turkey and they do not need to know English to become a successful doctor. It may also be related to the fact that education offered in Faculty of Medicine is not English medium and they do not think it is necessary to learn English in order to be successful in their departments.

Although most of the students have highly positive attitudes toward learning English language, this does not have a clear effect on their success. There is nearly no correlation between the attitudes of students at the Medicine, Education and Veterinarian Faculties and their achievement. The reason for this may be related to the fact that one-year intensive English instruction is obligatory for these departments and that they take English courses because it was a required course, not because they were strongly motivated to learn English. Thus, these students may feel forced to learn English language. On the other hand, it is surprising not to find any correlation between achievement and the attitudes of the students at the Foreign Trade Department and Maritime and Port. The students think that they would not need English later in their education since the medium of instruction in their departments was not English.

The results of the study indicated that for a considerable majority of the students there was positive correlation between their attitudes and their intrinsic motivation, instrumental motivation and parental involvement. As for the relations between the students' attitudes and their gender, female students tended to have higher scores than male students. The study revealed that some fields of study displayed significant differences in terms of their attitudes toward English language.

Since the data showed that the students at the tertiary level had moderate level of instrumental motivation and intrinsic motivation, the language teachers can easily boost their students' instrumental motivation by preparing the learners for the proficiency exam. Likewise, they can occasionally remind them their future goals and emphasize practical use of English such as how to communicate with other people when they travel to English-speaking countries. Teachers may also lay stress upon the importance of having a good knowledge of English in order to find a good job and to be able to understand the academic courses. Wei (2007) states that not only instrumental motivation but also intrinsic orientation of learners should be supported, which needs to be taken into consideration as it facilitates the reduction of anxiety that learners feel in language classrooms. Therefore, a balanced development of both instrumental and intrinsic motivations should be sustained.

Teachers can integrate the traditions, literature or lifestyle of the English-speaking countries into English courses by means of visual and audio materials. Written and visual materials might provide the learners with the opportunities to get to know the native speakers of English language and their culture. Another possible solution could be to increase language contact through partnerships among schools via internet or exchange programs that will enable students to visit other countries and host people from target societies. 


\section{Conclusion}

The main purpose of this study was to examine Gardner's proposition that there is a relation between attitudes and achievement and to investigate the motivation type and other factors such as gender, parental involvement, learners' fields of study and academic achievement. The results of the study showed that there was a low correlation between achievement and intrinsic motivation and instrumental motivation; however, there was not a significant correlation between the students' attitudes and "achievement" and "parental involvement" variables. The study also revealed that female learners have significantly more positive attitudes although almost all the participants indicated a positive attitude towards learning English language.

This study might contribute to EFL teachers' understanding of learner attitudes, motivational factors by demonstrating that learners' attitudes should be kept in mind in the teaching process. The study unveiled the learners' motivation and attitudes toward learning English and analysed the factors that influence their attitudes. EFL teachers at intensive English programs at universities often face demotivation problems in their classrooms. Even though the findings of this study are not completely generalizable, they may guide teachers in English language programs at other universities in terms of considering the significance of being sensitive to learners' motives and attitudes.

Among the limitations of this study, the first one is that this investigation was conducted at a state university. Different results could potentially be obtained at other universities differing in size, location and curriculum along with a different proficiency exam type. Further research might use a more developed attitude scale and a socioeconomic status scale including the attitudes of learners towards English culture and various English-speaking societies.

This study could be expanded to include other universities in Turkey and English language learners in other countries, which may help us compare and contrast the attitudinal profiles of the students from different universities in different EFL contexts. Teachers' views on the types of motivation and attitudes that their students have toward learning English might be investigated in order to find out whether the students' responses to the questionnaire reflect their actual behaviour, and whether there are matches or mismatches between teachers and learners in terms of the issues examined. Researchers can also investigate students' attitudes in terms of contextual variables such as attitudes toward the teacher, course book, course, and the learning environment where the process of learning English language takes place.

\section{References}

Al-Tamimi, A., \& Shuib, M. (2009). Motivation and attitudes towards learning English: A study of petroleum engineering undergraduates at Hadhramout University of Sciences and Technology. GEMA Online Journal of Language Studies, 9, 29-55.

Atl1, I. (2008). Young Language Learners' Attitude towards English Lessons in Turkish Elementary Schools. Unpublished Master's Thesis, On Dokuz Mayıs University, Samsun, Turkey.

Aydin, E. (2007). An Analysis of Motivations, Attitudes, and Perceptions of the Students at TOBB University of Economics and Technology toward Learning English as a Foreign Language. Unpublished Master's Thesis, Hacettepe University, Ankara, Turkey.

Bidin, S., Kamaruzaman, J., Nurazila, A. A., Musdiana, M. S., \& Tanizia, T. (2009). Motivation and attitude in learning English among UITM students in the northern region of Malaysia. English Language Teaching, 2, 16-20. http://dx.doi.org/10.5539/elt.v2n2p16

Carr, J., \& Pauwels, A. (2006). Boys and foreign language learning: Real boys don't do languages. Basingstoke: Palgrave Macmillan. https://doi.org/10.1057/9780230501652

Chambers, G. N. (1999). Motivating language learners. Clevedon: Multilingual Matters. https://doi.org/10.1080/09571739985200021

Çolak, A. (2008). Attitudes, Motivation and Study Habits of English Language Learners: The Case of Başkent University Second-Year Students. Unpublished Master's Thesis, Middle East Technical University, Ankara, Turkey.

Cortes, K. H. (2002). Youth and the study of foreign language: An investigation of attitudes. Foreign Language Annals, 35, 320- 332. https://doi.org/10.1111/j.1944-9720.2002.tb01857.x

Demirtas, S. (2007). An Investigation into Parental Attitudes towards English Language Learning and Students' Perception of Their Parents' Attitudes. Unpublished Master's Thesis, Çanakkale Onsekiz Mart University, Çanakkale, Turkey. 
Dogancay-Aktuna, S. (1998). The spread of English in Turkey and its current sociolinguistic profile. Journal of Multilingual and Multicultural Development, 19, 24-39. http://dx.doi.org/10.1080/01434639808666340

Firat, A. (2009). A Study on Young Learners' Attitudes towards English. Unpublished Master's Thesis, Çukurova University, Adana, Turkey.

Friedrich, P. (2000). English in Brazil: Functions and attitudes. World Englishes, 19(2), 215-223. https://doi.org/10.1111/1467-971X.00170

Fullan, M. (2001). The new meaning of educational change ( $3^{\text {rd }}$ edition). New York: Teachers College Press.

Gardner, R. C., \& Lambert, W. E. (1972). Attitudes and motivation in second language learning. Rowley, MA: Newbury House Publishers.

Gardner, R. C. (1985). Social psychology and second language learning: The role of attitudes and motivation. London: Edward Arnold.

Gomleksiz, M. N. (2010). An evaluation of students' attitudes toward English language learning in terms of several variables. Procedia: Social and Behavioral Sciences, 9, 913-918. http://dx.doi.org/10.1016/j.sbspro.2010.12.258

Haitema, T. B. (2002). Student Attitude Vis a Vis Foreign Language in the Elementary School (FLES): A Longitudinal Study. Unpublished Doctoral Dissertation, University of North Carolina, Chapel Hill.

Hang, P. (2009). Impacts of Vietnam's social context on learners' attitudes towards foreign languages and English language learning: Implications for teaching and learning. Asian EFL Journal, 11(4), 169-188.

Hawley, P. (1971). What women think men think: Does it affect their career choice? Journal of Counselling Psychology, 18(3), 193-199. https://doi.org/10.1037/h0030869

Hoover-Dempsey, K., Walker, J. M. T., Sandler, H. M., Whetsel, D., Green, C. L., Wilkins, A. S., \& Closson, K. (2005). Why do parents become involved? Research findings and implications. Elementary School Journal, 106, 105-130. https://doi.org/10.1086/499194

İnal, S., Evin, İ., \& Saracaloğlu, A. S. (2005). The relationship between students' attitudes toward foreign language and foreign language achievement. Paper presented at First International Conference Dokuz Eylül University Buca Faculty of Education, 1-3 October, İzmir, Turkey. Retrieved from dergiler.ankara.edu.tr/dergiler/27/.../9618.pdf

Karaş, M. (1996). Using attitude scale to investigate student attitude. Paper presented at the 2. IATEFL Balkan ELT Conference, 5-7 September, İstanbul, Turkey.

Kiziltepe, Z. (2000). Attitudes and motivation of Turkish EFL students towards second language learning. ITL International Journal of Applied Linguistics, 130, 141-168. https://doi.org/10.1075/itl.129-130.01kiz

Kobayashi, Y. (2002). The role of gender in foreign language learning attitudes: Japanese female students' attitudes towards English learning. Gender and Education, 14, 181-197. http://dx.doi.org/10.1080/09540250220133021

König, G. C. (1990). The place of English in Turkey. In D. Bozer (Ed.), The birth and growth of a department: Department of English language and literature: 25th anniversary (pp. 157- 167). Hacettepe University, Ankara

Liu, M. (2007). Chinese students' motivation to learn English at the tertiary level. Asian EFL Journal, 9, 126-146.

Loulidi, R. (1989). Is language learning really a female business? Modern Languages, 70, 201-208.

Mantle-Bromley, C. (1995). Positive attitudes and realistic beliefs: Links to proficiency. The Modern Language Journal, 79, 372-386. http://dx.doi.org/10.1111/j.1540-4781.1995.tb01114.x

Malallah, S. (2000). English in an Arabic environment: Current attitudes to English among Kuwait University students. International Journal of Bilingual Education and Bilingualism, 1, 19-43. http://dx.doi.org/10.1080/13670050008667698

Pennycook, A. (2004). Performativity and language studies. Critical Inquiry in Language Studies, 1-19. http://dx.doi.org/10.1207/s15427595cils0101_1

Petrides, J. R. (2006). Attitudes and motivation and their impact on the performance of young English as a foreign language learners. Journal of Language and Learning, 5, 1-20. 
Qashoa, S. (2006). Motivation among learners of English in the secondary schools in the Eastern coast of the UAE. Unpublished Master's Thesis, British University, Dubai.

Rees, F. (1987). The wrong gender. Modern Languages, 68, 183-187.

Ryan, R. M., \& Deci, E. L. (2000). Intrinsic and extrinsic motivations: Classic definitions and new directions. Contemporary Educational Psychology, 25, 54-67. https://doi.org/10.1006/ceps.1999.1020

Saracaloğlu, A. S. (2000). The relation between trainee teachers' attitudes to foreign languages and their academic success. Eğitim ve Bilim Dergisi, 25, 65-72.

Sebüktekin, H. (1981). Yüksek öğretim kurumlarımızda yabancı dil izlenceleri. Unpublished manuscript, Foreign language curricula in institutes of higher education, Bogaziçi University, Istanbul, Turkey.

Small, R. V. (1997). Assessing the motivational quality of world wide websites. ERIC Clearinghouse on Information and Technology, ED number pending, IR 018331.

Spolsky, B. (1989). Conditions for second language learning. Oxford: Oxford University Press.

Şeker, M. (2003). Attitudes toward language learning: A sociolinguistic study of preparatory students at ELT department at Çukurova University. Unpublished Master's Thesis, Çukurova University, Adana.

Tavil, Z. M. (2009). Parental attitudes towards English education for kindergarten students in Turkey. Kastamonu Eğitim Dergisi, 17, 331-340.

Thomas, J. A. (2010). How do I satisfy the general education language requirement? University students' attitudes toward language study. Foreign Language Annals, 43, 531-551. https://doi.org/10.1111/j.1944-9720.2010.01096.x

T1lfarloğlu, F. Y., \& Kınsız, M. (2011). Reasons for learning English in Turkey and the activities learners do to reach their goals, Contemporary Online Language Education Journal, 1, 52-61.

Üzüm, B. (2007). Analysis of Turkish learners' attitudes towards English language and English-speaking societies. Unpublished Master's Thesis, Institute of Social Sciences, Middle East Technical University, Ankara, Turkey.

Wei, M. (2007). The interrelatedness of affective factors in EFL learning: An examination of motivational patterns in relation to anxiety in China. TESL-EJ, 11(1).

Willams, M., \& Burden, R. L. (1997). Psychology for language teachers: A social constructivist approach. Cambridge: Cambridge University Press.

Young, M. Y. C. (2006). Macao students' attitudes toward English: a post-1999 survey. World Englishes, 25, 479-490. https://doi.org/10.1111/j.1467-971X.2006.00468.x

\section{Copyrights}

Copyright for this article is retained by the author(s), with first publication rights granted to the journal.

This is an open-access article distributed under the terms and conditions of the Creative Commons Attribution license (http://creativecommons.org/licenses/by/4.0/). 